\title{
KONTESTASI PENGETAHUAN NEGARA, SWASTA DAN MASYARAKAT DALAM PENGELOLAAN PROGRAM CORPORATE SOCIAL RESPONSIBILITY
}

\section{(The Contestation of Knowledge Between State, Private, and Community in The Corporate Social Responsibility Program)}

\author{
Mahmudi Siwi ${ }^{1)}$ \\ ${ }^{1)}$ Departemen Sains Komunikasi dan Pengembangan Masyarakat, Fakultas Ekologi Manusia, Institut Pertanian Bogor \\ Email: mahmudisiwi@apps.ipb.ac.id
}

\begin{abstract}
The management of the Corporate Social Responsibility (CSR) program is determined by the process of knowledge and power contestation in the governance of the CSR program. This contestation of knowledge about CSR often occurs on three social entities namely state, private, and community. Therefore, this research aims to examine the construction of knowledge of state, company, and community against the management of CSR program; and analyzing the political contestation (interests and powers) that occur at three social spaces in the management of CSR program. Research was conducted in Kembang Kuning village, Klapanunggal sub-district, Bogor district with critical paradigm using qualitative approach and case study method. The results showed that there are three forms of knowledge construction in CSR program. First, the construction that happens on the relationship between the community and the government that describes the CSR program as an aid. Second, the construction that happens on the relationship between the community and the company that describes the CSR program as an aid and obligation. Third, the construction that happens on the relationship between the government and the company that describes the CSR program as an obligation. The construction of this knowledge ultimately affects the dispute of interest which is make the low-class community becomes marginalized. Therefore, knowledge of CSR is constructed in such a manner as to provide higher economic benefits to the upper classes (high-class community, government, and company).
\end{abstract}

Keywords: contestation, corporate social responsibility program, knowledge, relation

\begin{abstract}
ABSTRAK
Pengelolaan program Corporate Social Responsibility (CSR) ditentukan oleh proses kontestasi pengetahuan dan kekuasaan dalam tatakelola program CSR. Kontestasi pengetahuan tentang CSR sering terjadi pada tiga entitas sosial yakni negara, swasta dan masyarakat. Oleh karena itu, penelitian ini bertujuan untuk mengkaji konstruksi pengetahuan negara, perusahaan dan masyarakat terhadap pengelolaan program CSR; dan menganalisis kontestasi politik (kepentingan dan kekuasaan) yang terjadi di tiga ruang sosial dalam pengelolaan program CSR. Penelitian dilaksanakan di desa Kembang Kuning, Kecamatan Klapanunggal, Kabupaten Bogor dengan paradigma kritis menggunakan pendekatan kualitatif dan metode studi kasus. Hasil penelitian menunjukkan bahwa terdapat tiga bentuk konstruksi pengetahuan dalam program CSR. Pertama, konstruksi yang terjadi pada relasi antara masyarakat dengan pemerintah yang menggambarkan program CSR sebagai bantuan. Kedua, konstruksi yang terjadi pada relasi antara masyarakat dengan perusahaan yang menggambarkan program CSR sebagai bantuan dan kewajiban. Ketiga, konstruksi yang terjadi pada relasi antara pemerintah dengan perusahaan yang menggambarkan program CSR sebagai kewajiban. Konstruksi kuasa pengetahuan ini pada akhirnya mempengaruhi konstestasi kepentingan dimana masyarakat lapisan bawah menjadi termarjinalkan. Oleh karena itu, pengetahuan CSR dikonstruksi dan dikontestasikan sedemikian rupa dalam rangka memberikan keuntungan ekonomi yang lebih kepada kelas atas (masyarakat lapisan atas, pemerintah dan perusahaan).
\end{abstract}

Kata kunci: kontestasi, pengetahuan, program corporate social responsibility, relasi 


\section{PENDAHULUAN}

Setiap perusahaan pasti memiliki dampak operasi yang dirasakan oleh pemangku kepentingan terutama masyarakat sekitar perusahaan. Oleh karena itu, semakin besar sebuah perusahaan maka dampak operasi perusahaan juga semakin besar sehingga ekspektasi dari pemangku kepentingan terhadap tanggungjawab sosial perusahaan (Corporate Social Responsibility/CSR) bagi masyarakat sekitar juga akan membesar (Welford dalam Jalal 2011). Welford (Jalal 2011) juga menjelaskan bahwa program CSR ditujukan sebagai antisipasi bukan sebagai reaksi terhadap dampak operasinya.

PT. Holcim Indonesia (selanjutnya disebut HIL) jauh sebelum isu CSR menjadi populer di Indonesia, HIL telah menjalankan berbagai program yang ditujukan bagi masyarakat sekitar operasi sebagai bentuk ganti rugi terhadap dampak operasi. Kondisi ini menunjukkan bahwa HIL telah memperhatikan pemangku kepentingannya terutama masyarakat sekitar sebagai bentuk program CSR. Namun, merujuk pada pandangan Welford diatas, programprogram tersebut masih sebagai reaksi terhadap masyarakat sekitar yang melakukan protes karena telah terjadi kerusakan-kerusakan di lingkungan seperti rumah yang retak-retak karena peledakan, tidak bisa akses sumberdaya alam yang ada di kawasan tambang, dan pencemaran lingkungan.

Hasil penelitian sebelumnya yang dilakukan oleh Asrianti (2010) dan Radiati (2010) menunjukkan bahwa program CSR sebagai etika bisnis perusahaan dilakukan mulai dari bentuk charity hingga corporate citizenship. Hal tersebut tidak terlepas dari konstruksi pengetahuan dan kekuasaan tentang pengelolaan program CSR yang dibangun, disosialisasikan dan dikontestasikan dalam entitas sosial. Fenomena tersebut menunjukkan bahwa program CSR ditafsirkan berbeda-beda oleh tiap entitas sosial (pemerintah, perusahaan dan masyarakat) yang "berkepentingan" terhadap program CSR tersebut. Pemikiran Foucault (Wulan 2010; Malik 2010) tentang pengetahuan dan kekuasaan, memberikan penjelasan bahwa pemahaman yang berbeda-beda antara negara (state), perusahaan, dan masyarakat menunjukkan adanya perbedaan pengetahuan dan kekuasaan yang bekerja dalam membentuk, mewarnai dan mengarahkan pemahaman tentang pengelolaan program CSR dalam tiga ruang sosial tersebut. Disinilah, perbedaan konstruksi pengetahuan tentang pengelolaan program CSR akan menyebabkan kontestasi kepentingan dan kekuasaan antar tiga ruang sosial.

Dalam implementasi program CSR terdapat 6 (enam) isu utama CSR yang salahsatunya adalah community involvement and development yang intinya mengedepankan proses-proses partisipasi dan pemberdayaan masyarakat dalam setiap aktivitas pengelolaan program CSR. Namun pada kenyataannya, praktek CSR di Indonesia masih sekedar membangun image perusahaan daripada membangun proses pemberdayaan masyarakat (Radyati 2008). Hal tersebut menunjukkan bahwa pengelolaan program CSR dipandang sebagai fenomena politik, dimana negara, perusahaan dan masyarakat saling bertemu melalui konstruksi pengetahuan dan kontestasi kepentingan dan kekuasaan yang pada akhirnya melupakan tujuan utama program CSR yakni untuk kesejahteraan masyarakat melalui proses partisipasi dan pemberdayaan masyarakat. Oleh karena itu, menjadi penting untuk melihat bagaimana dan sejauhmana kontestasi pengetahuan antara negara, swasta dan masyarakat dalam pengelolaan program CSR?

Terdapat 2 (dua) rumusan masalah yang diajukan dalam penelitian ini. Pertama, bagaimana dan sejauhmana konstruksi negara, perusahaan dan masyarakat terhadap program CSR HIL yang akan menentukan proses dinamika politik dalam pengelolaan program CSR HIL? Hal ini didasari oleh pemikiran Foucault (1984) tentang pengetahuan dan kekuasaan, yang memberikan penjelasan bahwa konstruksi yang berbeda-beda antara negara, perusahaan, dan masyarakat merupakan hasil kontestasi perbedaan kuasa pengetahuan yang bekerja dalam membentuk, mewarnai dan mengarahkan pemahaman tentang realitas sosial dalam tiga ruang sosial tersebut. Program CSR sebagai realitas sosial ditafsirkan berbeda-beda oleh tiap stakeholder (aktor) yang "berkepentingan" yang menunjukkan bahwa terdapat pengetahuan dan kekuasaan yang berbeda dalam pengelolaan program CSR. Perbedaan konstruksi pengetahuan terhadap 
pengelolaan program CSR pada akhirnya akan mempengaruhi dinamika politik dalam pengelolaan program CSR.

Kedua, bagaimana dan sejauhmana kontestasi politik (kepentingan dan kekuasaan) dalam tiga ruang sosial (negara, perusahaan dan masyarakat) dalam pengelolaan program CSR HIL? Merujuk pandangan Foucault (Mills 2007; Malik 2010) bahwa pengetahuan dan kekuasaan saling melahirkan, dan tidak ada pengetahuan tanpa kekuasaan begitu pula sebaliknya maka kontestasi politik (kepentingan dan kekuasaan) yang terjadi dalam pengelolaan program CSR merupakan hasil dari konstruksi pengetahuan yang berbeda-beda ketiga entitas sosial terhadap program CSR. Berdasarkan pandangan tersebut, maka dalam praktek CSR dapat dipahami sebagai sebuah bentuk pertarungan kepentingan dan kekuasaan yang bersumber pada otoritas yang dimiliki oleh masing-masing entitas sosial sebagai hasil konstruksi kuasa pengetahuan.

Tujuan utama penelitian ini adalah untuk melakukan kajian terhadap kontestasi pengetahuan negara, swasta dan masyarakat dalam pengelolaan program CSR HIL di Desa Kembang Kuning, Kecamatan Klapanunggal, Kabupaten Bogor. Adapun tujuan penelitian secara lebih rinci dirumuskan sebagai berikut: (1) Mengkaji konstruksi pengetahuan negara, perusahaan dan masyarakat terhadap pengelolaan program CSR HIL Pabrik Narogong; dan (2) Menganalisis kontestasi politik (kepentingan dan kekuasaan) yang terjadi di tiga ruang sosial (negara, perusahaan dan masyarakat) dalam pengelolaan program CSR HIL Pabrik Narogong.

\section{PENDEKATAN TEORITIS}

\section{Perkembangan Implementasi CSR di Indonesia}

Perkembangan implementasi CSR di Indonesia dapat dikatakan sudah cukup baik, meskipun masih terjadi perdebatan mengenai status program CSR apakah wajib atau sukarela? Tidak hanya itu, perdebatan juga terjadi dalam definisi program CSR. Namun penelitian ini meruujuk definisi CSR dalam ISO 26000 yang merupakan standar pengelolaan program CSR yang berlaku secara internasional, dimana CSR didefinisikan sebagai responsibility of an organization or the impacts of its decisions and activities on society and the environment, through transparant and ethical behaviour that contibutes to sustainable development, health and welfare of society; takes into account the expectations of stakeholders; is in compliance with applicable law and is integrated throughout the organization and practiced its relationships (Moratis dan Cochius 2011). Sedangkan Sukada, et al. (2007) mendefinisikan CSR sebagai upaya sungguh-sungguh dari perusahaan untuk meminimumkan dampak negatif dan memaksimumkan dampak positif operasinya dalam ranah ekonomi, sosial, dan lingkungan, terhadap seluruh pemangku kepentingannya, untuk mencapai tujuan pembangunan berkelanjutan. Merujuk pada kedua definisi tersebut terlihat bahwa isu pembangunan berkelanjutan menjadi tujuan utama dalam pelaksanaan program CSR.

Berdasarkan ISO 26000 terdapat 6 (enam) prinsip dalam implementasi CSR (Moratis dan Cochius 2011), yakni community involvement and development, human rights, labor practices, fair operating practices, consumer issues, and the environment. Hanya saja praktek CSR di Indonesia menunjukkan bahwa isu community involvement and development belum menjadi perhatian bagi pelaku bisnis, sehingga seringkali program CSR hanya membangun image saja.

\section{Definisi dan Dimensi Corporate Social Reponsibility}

Dalam konteks global, istilah CSR mulai digunakan sejak tahun 1970an dan semakin populer terutama setelah kehadiran buku Cannibals With Forks: The Triple Bottom Line in $21^{\text {st }}$ Century Business (1998), karya John Elkington. Mengembangkan tiga komponen penting sustainable development, yakni economic growth, environmental protection, dan social equity. Elkington mengemas CSR ke dalam tiga fokus yakni 3P, singkatan dari profit, planet dan people. Perusahaan yang baik tidak hanya memburu keuntungan ekonomi belaka (profit). Melainkan pula memiliki kepedulian terhadap kelestarian lingkungan (planet) dan kesejahteraan masyarakat (people).

Terdapat banyak diskursus dalam pemahaman konsep CSR. Pada awalnya, konsep CSR merupakan suatu pendekatan perubahan atau pengembangan masyarakat khususnya 
peningkatan sumberdaya manusia yang dilakukan oleh suatu perusahaan sebagai bagian dari tanggungjawab sosialnya. Pendekatan ini berasal dari pemikiran bahwa perusahaan harus turut berkontribusi terhadap pembangunan dimana lokasi perusahaan beroperasi. Oleh karenanya, CSR lahir sebagai sebuah etika bisnis baru dalam sejarah perkembangan kapitalisme global. Pendekatan CSR ini bertujuan agar masyarakat turut terlibat atau menjadi bagian dari perusahaan tersebut dan menikmati manfaat dari keberadaan perusahaan di suatu wilayah tertentu.

Dalam ISO 26000 yang merupakan standar pelaksanaan CSR yang berlaku secara internasional, CSR didefinisikan sebagai responsibility of an organization or the impacts of its decisions and activities on society and the environment, through transparant and ethical behaviour that contibutes to sustainable development, health and welfare of society; takes into account the expectations of stakeholders; is in compliance with applicable law and is integrated throughout the organization and practiced its relationships (Moratis dan Cochius, 2011). World Business Council for Sustainable Development (WBCSD) (Sukada, et al. 2007), mendefinisikan CSR sebagai komitmen untuk berkontribusi terhadap pembangunan ekonomi yang berkelanjutan; berkerja dengan para karyawan dan keluarganya, masyarakat setempat dan masyarakat secara luas dalam meningkatkan kualitas hidup mereka. Definisi lain menurut Sukada, et al. (2007) yang mendefinisikan CSR sebagai upaya sungguhsungguh dari perusahaan untuk meminimumkan dampak negatif dan memaksimumkan dampak positif operasinya dalam ranah ekonomi, sosial, dan lingkungan, terhadap seluruh pemangku kepentingannya, untuk mencapai tujuan pembangunan berkelanjutan.

Kotler dan Lee (2005) dalam Sumaryo (2009) menyatakan bahwa CSR merupakan suatu komitmen untuk meningkatkan kesejahteraan masyarakat sebagai pertimbangan dalam praktik bisnis dan kontribusi dari sumberdaya perusahaan. Inti dari pengertian tersebut tidak mengacu pada aktivitas bisnis yang diatur oleh peraturan perundangan yang berlaku, namun lebih pada komitmen kerelawanan perusahaan sehingga dipilih dan diimplementasikan dalam praktik bisnisnya. Pandangan yang lebih komprehensif mengenai CSR yang kemudian disebut sebagai "teori Piramida CSR" dikemukakan oleh Carol dalam Nursahid (2006) bahwa tanggungjawab sosial perusahaan dapat dilihat berdasarkan empat jenjang (ekonomis, hukum, etis dan filantropis) yang merupakan satu kesatuan. Untuk memenuhi tanggungjawab ekonomis, sebuah perusahaan harus menghasilkan laba sebagai pondasi untuk mempertahankan perkembangan dan eksistensinya.

Dari berbagai definisi CSR yang ada, Alexander Dahlsrud dalam tulisannya How Corporate Social Responsibility is Defined di jurnal Corporate Social Responsibility and Environmental Management (2008) menjelaskan dan menyimpulkan bahwa definisi CSR itu secara konsisten mengandung 5 dimensi, yaitu:

1. Dimensi Lingkungan yang merujuk ke lingkungan hidup dan mengandung katakata seperti "lingkungan yang lebih bersih", "pengelolaan lingkungan", "environmental stewardship", "kepedulian lingkungan dalam pengelolaan operasi bisnis", dll.

2. Dimensi Sosial yaitu hubungan antara bisnis dan masyarakat dan tercermin melalui frase-frase seperti "berkontribusi terhadap masyarakat yang lebih baik", "mengintegrasi kepentingan sosial dalam operasi bisnis", "memperhatikan dampak terhadap masyarakat", dll.

3. Dimensi Ekonomis yang menerangkan aspek sosio-ekonomis atau finansial bisnis yang diterangkan dengan kata-kata seperti "turut menyumbang pembangunan ekonomi", "mempertahankan keuntungan", "operasi bisnis", dll.

4. Dimensi Pemangku Kepentingan (Stakeholder) yang tentunya menjelaskan hubungan bisnis dengan pemangku kepentingannya dan dijelaskan dengan katakata seperti "interaksi dengan pemangku kepentingan perusahaan", "hubungan perusahaan dengan karyawan, pemasok, konsumen dan komunitas", "perlakukan terhadap pemangku kepentingan perusahaan", dll.

5. Dimensi Kesukarelaan (voluntary) sehubungan dengan hal-hal yang tidak diatur oleh hukum atau peraturan yang 
tercermin melalui frase-frase seperti "berdasarkan nilai-nilai etika", "melebihi kewajiban hukum (beyond regulations)", "voluntary", dll.

\section{Pengembangan Masyarakat}

Dalam pengelolaan program CSR merujuk pada ISO 26000 terdapat 6 (enam) isu utama yang perlu diperhatikan, dimana terdapat isu community involvement and development yang harus dijalankan untuk mengelola dampak operasi perusahaan. Aktualisasi dari prinsip tersebut adalah program CSR dilaksanakan dalam kerangka pengembangan masyarakat. Pengembangan masyarakat merupakan strategi baru dalam proses pembangunan yang merupakan pergeseran paradigma dari production centered development menuju paradigma people centered development. Dunham (1958) dalam Adi (2003) mendefinisikan pengembangan masyarakat sebagai berbagai upaya yang terorganisir yang dilakukan guna meningkatkan kondisi kehidupan masyarakat, terutama melalui usaha yang kooperatif dan mengembangkan kemandirian dari masyarakat pedesaan, tetapi hal tersebut dilakukan dengan bantuan tehnis dari pemerintah ataupun lembaga-lembaga sukarela. Sedangkan Carry J (1970) dalam Hasim dan Remiswal (2009) yang menjelaskan community development pada hakekatnya adalah usaha yang dilakukan dengan sengaja oleh warga komunitas untuk bekerjasama yang diarahkan pada masa depan komunitas sendiri.

Pengembangan masyarakat diyakini merupakan sebuah aktualisasi dari CSR yang lebih bermakna daripada hanya sekedar aktivitas charity atau 6 (enam) dimensi CSR lainnya (Ambadar 2008). Hal ini didasarkan dalam pelakasanaan CD terdapat kolaborasi kepentingan bersama antara perusahaan dengan komunitas, adanya partisipasi, produktivitas dan keberlanjutan. Lebih lanjut dijelaskan bahwa untuk mewujudkan Good Corporate Governance (GCG) maka Good Corporate Citizenship (GCC) perlu dilakukan sebagai komitmen dunia usaha. Oleh karena itu, program-program yang ditujukan untuk meningkatkan kesejahteraan masyarakat tidak hanya sekedar charity tetapi juga dalam bentuk GCC yang menekankan pada penciptaan partisipasi dan pemberdayaan masyarakat.

\section{Pengetahuan dan Kekuasaan}

Karya-karya Michel Foucault memberikan kontribusi yang besar terhadap perkembangan ilmu sosial. Foucault memberikan pemahaman teori tentang rejim kebenaran dan teori tentang hubungan antara kebenaran dan kekuasaan. Ide Marxian juga ditemukan dalam karya Foucault (Ritzer dan Goodman 2010), tetapi ia tidak membatasi dirinya pada ekonomi; ia memusatkan perhatian pada sejumlah besar institusi. Foucault lebih memusatkan perhatian "politik mikro kekuasaan" daripada memusatkan perhatian pada kekuasaan di tingkat kemasyarakatan sebagaimana yang dilakukan Marxian tradisional (Ritzer dan Goodman, 2010). Pandangan-pandangan Foucault yang sedikit banyak dipengaruhi oleh perspektif Marxian sehingga dapat dimasukkan dalam paradigma kritis.

Foucault menerapkan hermeneutika (hermeneutic) untuk dapat memahami fenomena sosial yang menjadi sasaran perhatiannya dengan lebih baik. Foucault mengadopsi pemikiran Nietzsche tentang hubungan antara kekuasaan dan pengetahuan yang dianalisa secara sosiologis. Ada dua ide inti metodologi Foucault, yakni arkeologi ilmu pengetahuan dan genealogi kekuasaan (Ritzer 2007). Alan Sheridan (Ritzer dan Goodman, 2010) menjelaskan bahwa arkeologi pengetahuan karya Foucault meliputi upaya penelitian untuk menemukan "seperangkat aturan yang menentukan kondisi kemungkinan keseluruhan yang dapat dikatakan dalam diskursus khusus pada waktu tertentu". Dengan kata lain, arkeologi adalah pencarian sistem umum dari formasi dan transformasi pernyataan ke dalam formasi diskursif.

Diskursus sebagai ide pokok dalam pemikiran Foucault, dipahami sebagai penjelasan, pendefinisian, pengklasifikasian dan pemikiran tentang orang, pengetahuan dan sistem abstrak pemikiran (Malik 2010). Lebih lanjut dijelaskan bahwa diskursus tidak terlepas dari relasi kekuasaan dan bertautan dengan pengetahuan. Atas dasar konsepsi tersebut Foucault mendefinisikan kekuasaan berbeda dengan beberapa ahli lainnya. Bagi Foucault kuasa tidak bermakna "kepemilikan", atau keadaan di mana seseorang memiliki sumber kekuasaan. Kuasa, dipraktikkan dalam suatu ruang lingkup 
di mana ada banyak posisi yang secara strategis berkaitan satu sama lain (Wulan 2010).

Sumbangan terbesar Foucault terhadap teori dan praktik perubahan sosial adalah membuat teori itu lebih sensitif terhadap relasi kekuasan dan dominasi dan menyadarkan bagaimana relasi kekuasaan (power) teranyam di setiap aspek kehidupan serta kehidupan pribadi, dan ini bertentangan dengan umumnya keyakinan ilmu sosial yang cenderung mengabaikan "kekuasaan" dalam dunia ilmu pengetahuan, dan berasumsi bahwa pengetahuan itu netral, obyektif dan tak berdosa (Wulan 2010). Kecenderungan memandang bahwa kekuasaan hanya berpusat di negara ataupun kelas, bagi Foucault merupakan pengingkaran kenyataan, karena relasi kekuasaan terdapat pada setiap aspek kehidupan. Foucault berpendapat bahwa kekuasaan tersebar di mana-mana dan datang dari mana-mana (Mills 2007; Wulan 2010; Malik 2010). Pandangan ini berbeda dengan konsep kekuasaan yang dikemukakan oleh Marxian yang melihat kekuasaan hanya ada pada negara (Suseno 2003).

Lebih lanjut, Foucault secara khusus tertarik dengan diskursus-diskursus yang mencoba merasionalkan atau mensistematiskan dirinya sendiri dalam hubungannya dengan cara tertentu dari penyampaian kebenaran. Yang pada akhirnya kebenaran berhubungan langsung dengan genealogi kekuasaan, artinya pengetahuan dan kekuasaan saling berkaitan. Kekuasaan bagi Foucault (1980) dalam Malik (2010) merupakan dimensi kehidupan sosial yang fundamental yang tidak dapat dihindari dan kekuasaan mengalami transformasi sejalan dengan sejarah (Ritzer 2007), mengalami perubahan dari waktu ke waktu dalam bentuk yang berbeda. Foucault (Ritzer 2007) menjelaskan bahwa kekuasaan bukan sebagai sesuatu yang menjadi milik, akan tetapi lebih merupakan strategi, sehingga kekuasaan merupakan praktek yang terjadi dalam suatu ruang lingkup tertentu yang didalamnya ada banyak posisi yang terus mengalami pergeseran.

Hubungan antara kekuasaan dengan pengetahuan menurut Foucault, keduanya saling menyatakan antara satu dengan yang lain (Mills 2007; Ritzer 2007; Malik 2010). Lebih lanjut dijelaskan bahwa tidak ada relasi kekuasaan tanpa dinyatakan dalam hubungannya dengan wilayah pengetahuan, maka pengetahuan dan kekuasaan saling bertautan dengan erat, begitu juga proses historis terkait dengan kekuasaan. Pengetahuan bukan merupakan pengungkapan samar-samar dari relasi kuasa tetapi pengetahuan berada di dalam relasi-relasi kuasa itu sendiri. Tidak ada pengetahuan tanpa kuasa, dan sebaliknya tidak ada kuasa tanpa pengetahuan (Foucault 1980).

Hadirnya beragam kegiatan dalam program CSR, mulai dari charity hingga corporate citizenship menunjukkan bahwa setiap pemangku kepentingan memiliki pemahaman tersendiri terhadap program CSR. Fenomena tersebut menunjukkan bahwa program CSR ditafsirkan berbeda-beda oleh entitas sosial (negara, perusahaan dan masyarakat) yang "berkepentingan" terhadap program CSR tersebut. Merujuk pada pandangan Foucault diatas perbedaan penafsiran ini sangat terkait dengan diskursus kuasa pengetahuan dan kekuasaaan yang terjadi di tiga ruang sosial tersebut. Munculnya UU Perseroan Terbatas yang salahsatu pasalnya mengatur tentang pelaksanaan tanggungjawab sosial perusahaan merupakan suatu bukti pertarungan kuasa pengetahuan dan kekuasaan dalam implementasi program CSR. Dalam perkembangannya, beberapa pemerintah daerah seperti Jawa Timur, Sumatera Selatan dan Kalimantan Timur telah membuat peraturan daerah untuk pengaturan program CSR. Dalam perda tersebut, sangat jelas bahwa hanya kepentingan pemda saja yang menjadi perhatian ${ }^{1}$. Tidak hanya itu, hadirnya LSM yang bergerak dibidang CSR juga menunjukkan bahwa CSR telah menjadi kontestasi kepentingan dan kebijakan dalam tiga ruang sosial tersebut.

Pemikiran Foucault (1980) tentang pengetahuan dan kekuasaan, memberikan penjelasan bahwa pemahaman yang berbeda-beda antara negara (state), perusahaan, dan masyarakat menunjukkan adanya perbedaan pengetahuan dan kekuasaan yang bekerja dalam membentuk dan mewarnai dan mengarahkan pemahaman tentang CSR dalam tiga ruang sosial tersebut.

\footnotetext{
${ }^{1}$ Pandangan ini muncul sebagai hasil dari proses dialogis antara peneliti dengan informan di Lingkar Studi CSR (sebuah institusi yang bergerak di bidang CSR) tentang perkembangan tata peraturan perundangan di Indonesia yang mengatur program CSR
} 
Disinilah, kontestasi pengetahuan dan kekuasaan antar tiga ruang sosial terjadi terkait dengan implementasi program CSR sebagai bentuk dinamika politik dalam program CSR. Pada akhirnya, proses konstruksi pengetahuan tentang program CSR dan kontestasi kekuasaan karena kepentingan yang berbeda akan berpengaruh terhadap proses pemberdayaan masyarakat dalam program CSR.

\section{Kerangka Pemikiran}

Penelitian mengenai kontestasi pengetahuan negara, swasta dan masyarakat dalam pengelolaan program CSR dilatarbelakangi oleh adanya fenomena sosial bahwa masyarakat kelas bawah tidak memperoleh manfaat yang "adil" dengan adanya program CSR. Hasil penelitian menunjukkan bahwa pelaksanaan program CSR hanya 'dinikmati' oleh kalangan kelas atas. Dalam pandangan Marxis, masyarakat kelas bawah tetap dalam posisi termarginalkan dalam proses pembangunan pedesaan, begitu juga dalam kasus pembangunan pedesaan melalui program CSR. Kondisi ini justru mengakibatkan masyarakat kelas bawah tidak mengalami proses tranformasi menuju kemandirian secara ekonomi, sosial dan politik. Hadirnya program CSR mulai dari yang bersifat charity, philanthropy hingga corporate citizenship menunjukkan bahwa program CSR dimaknai berbeda-beda oleh pemangku kepentingan dalam tiga ruang sosial, yakni negara, perusahaan dan masyarakat. Dalam pandangan Foucault (1984) perbedaan bentuk program CSR ini terkait dengan perbedaan penafsiran (konstruksi) tentang realitas sosial (pengelolaan program CSR) pada masing-masing entitas sosial maupun antar entitas sosial. Lebih lanjut Foucault (1984) menjelaskan bahwa perbedaan penafsiran ini sangat terkait dengan diskursus kekuatan pengetahuan dan kekuasaan yang terjadi di tiga ruang sosial tersebut. Disinilah, dinamika politik dilihat dari berbagai konstruksi pengetahuan dan kontestasi kepentingan dan kekuasaan antar tiga ruang sosial terjadi terkait dengan pengelolaan program CSR.

Fenomena kontestasi kepentingan dan kekuasaan pengelolaan program CSR antar aktor dalam tiga ruang sosial pada akhirnya melupakan tujuan utama program CSR yakni untuk mencapai kesejahteraan masyarakat melalui proses partisipasi dan pemberdayaan masyarakat. Ambadar (2008) berpandangan bahwa dalam konteks hubungan perusahaan dan masyarakat di Indonesia terkait program CSR, maka bentuk pemberdayaan masyarakat (community empowerment) harus menjadi arus utama dari keenam isu pokok dalam pengelolaan program CSR. Isu community involvement and develompment harus menjadi bagian terpenting dalam program karena masyarakat sebagai bagian stakeholders yang paling lemah. Program CSR yang secara definisi diberikan kepada masyarakat yang terkena dampak, justru menjadi pertarungan kepentingan dan kekuasaan pada tiga ruang entitas sosial tersebut.

\section{METODE PENELITIAN}

Penelitian ini merupakan bagian dari penelitian yang dilaksanakan oleh Departemen Sains Komunikasi dan Pengembangan Masyarakat yang berjudul "Persepsi Komunitas dan Pemangku Kepentingan Lainnya terhadap Pengembangan Masyarakat dalam Kerangka Tanggung Jawab Sosial PT Holcim Indonesia Tbk Pabrik Narogong". Paradigma penelitian yang digunakan adalah paradigma kritis yang bertujuan untuk membongkar masalah relasi kekuasaan dan kontestasi para aktor dalam tiga ruang entitas sosial yang mendasari pengelolaan program CSR HIL. Penelitian ini menggunakan pendekatan kualitatif dengan metode studi kasus. Penelitian dilaksanakan di Desa Kembang Kuning, Kecamatan Klapanunggal, Kabupaten Bogor selama kurang lebih sekitar 6 (enam) bulan dari bulan Juli - Desember 2011. Penelitian ini melibatkan sekitar 5 informan dari kalangan pemerintah, perusahaan, masyarakat dan LSM. Sedangkan responden yang diwawancarai sebanyak 15 orang dari kalangan pemerintah, perusahaan dan masyarakat. Meskipun penelitian ini didasarkan pada wawancara aktor-aktor yang terlibat dalam pengelolaan dan penerima program CSR HIL, namun analisis yang digunakan dalam penelitian ini berada pada tingkat komunitas.

\section{HASIL DAN PEMBAHASAN}

\section{Konstruksi Sosial Kuasa Pengetahuan dalam Pengelolaan Program CSR}

Fenomena pengelolaan program CSR merupakan realitas sosial dalam proses 
pembangunan pedesaan. Sebagai realitas sosial maka pengelolaan program CSR dibangun atas pengetahuan yang kemudian saling dikonstruksikan oleh entitas sosial (pemerintah, swasta dan masyarakat). Foucault (1984) berpendapat bahwa masing-masing entitas sosial akan membangun pengetahuannya terhadap realitas sosial sehingga akan terjadi perbedaan pengetahuan baik di dalam entitas sosial maupun antar entitas sosial. Terkait dengan pengelolaan program CSR, konstruksi sosial kuasa pengetahuan dapat dilihat dari pola relasi dalam 3 (tiga) bentuk. Pertama, konstruksi kuasa pengetahuan yang terbentuk dari relasi antara pemerintah dengan masyarakat. Pada kasus ini, kuasa pengetahuan pengelolaan program CSR ditemukan dalam kelembagaan pembangunan desa yakni musrenbang. Pada kelembagaan inilah ditemukan pengetahuan pengelolaan program CSR dikonstruksi, disosialisasikan dan direproduksi kembali. Sedangkan pemegang kuasa pengetahuan berada pada pemerintah desa dan masyarakat lapisan atas. Terdapat dua konstruksi pengetahuan pengelolaan program CSR. Pertama, CSR dikonstruksikan sebagai hak warga atau kewajiban perusahaan, sehingga baik warga maupun pemerintah desa berhak untuk menuntut kepada perusahaan. Konstruksi ini terjadi dalam relasi antara pemerintah desa dengan masyarakat lapisan atas. Kedua, CSR dikonstruksikan sebagai program bantuan atau hibah. Konstruksi ini dibangun oleh pemerintah desa dan masyarakat lapisan atas dalam relasi antara pemerintah desa dan masyarakat lapisan atas dengan masyarakat lapisan menengah dan bawah. Sebagaimana yang diungkapkan oleh Kepala Desa dalam forum pertemuan dengan warga, sebagai berikut:

$$
\begin{aligned}
& \text { “..tahun ini desa Kembang Kuning } \\
& \text { mendapat bantuan program dari } \\
& \text { Holcim sebesar 200 juta, } \\
& \text { penggunaannya untuk infrastruktur, } \\
& \text { pemberdayaan ekonomi, pendidikan } \\
& \text { dan sosial” (Kepala Desa Kembang } \\
& \text { Kuning, 2010) }
\end{aligned}
$$

$\underline{\text { Kedua }}$, konstruksi kuasa pengetahuan yang terbentuk dalam relasi antara perusahaan dan masyarakat. Sejak perusahaan Semen Cibinong diambil alih dan berganti menjadi HIL pengelolaan program CSR di desentralisasi kepada pemerintah desa. Namun, untuk menjaga agar program CSR HIL tepat sasaran maka HIL turut terlibat dalam proses pengelolaan program seperti dalam perencanaan, pelakasanaan, evaluasi dan monitoring. Pada kasus ini, kuasa pengetahuan pengelolaan program CSR berada dalam kelembagaan Forum Komunikasi Masyarakat (FKM) dengan pemegang kuasa pengetahuan berada di staf Comrel HIL. Forum Komunikasi Masyarakat (FKM) merupakan sebuah forum yang dilaksanakan oleh HIL untuk merencanakan dan mengevaluasi program CSR di desa binaan. Dalam setahun FKM dilaksanakan 2 (dua) kali, diawal dan diakhir tahun. Selain untuk merencanakan dan mengevaluasi program CSR, FKM juga dimanfaatkan oleh staf Comrel HIL untuk membangun dan mensosialisasikan pengetahuan program CSR.

Kuasa pengetahuan pengelolaan program CSR HIL berada pada bagian community relations (comrel) sebagai bagian yang bertanggungjawab terhadap pelaksanaan program CSR HIL. Pada bagian comrel inilah pengetahuan Program CSR dibangun, disosialisasikan, dipertentangkan, dan diperbarui sesuai dengan visi dan misi perusahaan. Jika mempelajari dokumen strategis program CSR HIL, terlihat bahwa pengetahuan pengelolaan program CSR HIL didasarkan pada pemahaman staf Comrel atas prinsip pembangunan berkelanjutan. Bagi HIL, CSR dipahami sebagai “...HIL's commitment to work as partners with all our stakeholders, building and maintaining relationships of mutual respect and truts" (CSR Policy, HIL 2009). Sedangkan misi program CSR HIL adalah "As part of Holcim's commitment to sustainable development, we recognize our social responsibilities and aim to visibly play a leading role of our sphere of influence" (CSR Policy, HIL, 2009). Berdasarkan visi dan misi inilah oleh HIL program CSR dipahami sebagai bagian dari strategi perusahaan bukan sebagai program yang bersifat wajib.

Namun, hasil pengamatan dilapang menunjukkan bahwa program CSR disosialisasikan oleh HIL sebagai program bantuan baik kepada masyarakat lapisan atas maupun lapisan menengah dan bawah. Disinilah terjadi perbedaan pengetahuan pada masyarakat lapisan atas maupun lapisan menengah dan bawah dengan perusahaan. Konstruksi kuasa 
pengetahuan yang dibangun oleh perusahaan sebagai program bantuan dengan mudah diterima oleh masyarakat lapisan menengah dan bawah. Sedangkan dengan masyarakat lapisan atas terjadi benturan pengetahuan dimana masyarakat lapisan atas mengkonstruksi sebagai kewajiban perusahaan.

$\underline{\text { Ketiga }}$, konstruksi kuasa pengetahuan yang terbentuk dalam relasi antara pemerintah dan perusahaan. Berbeda dengan dua bentuk konstruksi pengetahuan sebelumnya, dimana kuasa pengetahuan dibangun dan diinternalisasikan cenderung dikuasai oleh salah satu pihak, pada bentuk ketiga baik pemerintah maupun perusahaan sama-sama sebagai pemegang kuasa pengetahuan pengelolaan program CSR. Disinilah masing-masing entitas sosial ini saling mengkonstruksi pengetahuan pengelolaan program CSR. Pemerintah yang dalam penelitian ini diwakili oleh pemerintah desa membangun pengetahuan bahwa program CSR sebagai kewajiban dari perusahaan sebagai bentuk tanggungjawab terhadap dampak operasi perusahaan sehingga pemerintah desa menuntut adanya program CSR di desa Kembang Kuning. Hal ini berbeda dengan konstruksi pengetahuan yang dibangun oleh HIL bahwa program CSR merupakan bagian strategi perusahaan sehingga program CSR dipandang sebagai sebuah kesukarelaan.

Dalam pengelolaan program CSR HIL, baik perusahaan maupun pemerintah desa sama-sama membangun kuasa pengetahuan tentang proses pengusulan program. Pengetahuan yang dibangun dan disosialisasikan adalah setiap program CSR HIL yang akan diajukan ke perusahaan harus mendapatkan persetujuan dari pemerintah desa. Artinya masyarakat sekitar yang ingin mengajukan proposal untuk memperoleh dana CSR HIL maka proposal tersebut sudah menjadi bagian dari rencana penggunaaan dana CSR yang dialokasikan oleh desa. Hal inilah yang kemudian menjadi permasalahan baik di masyarakat maupun pemerintah. Masyarakat terutama lapisan bawah menjadi tidak akses terhadap program CSR HIL, sedangkan pemerintah kecamatan terjadi gesekan dengan pemerintah desa karena merasa tidak dilibatkan dalam proses pengelolaan program.

\section{Kontestasi Kepentingan dan Kekuasaan terhadap Pengelolaan Program CSR}

Program CSR sebagai sebuah perspektif strategi bisnis perusahaan pada dasarnya berasal dari pemikiran kapitalisme. Menurut Marx kapitalisme adalah sistem ekonomi bebas tanpa batas yang ditentukan semata-mata oleh keuntungan yang lebih besar (Suseno 2003:164). Lebih lanjut Marx menjelaskan bahwa dalam sistem kapitalisme proses produksi atau membeli bukan karena untuk digunakan, melainkan karena ingin menjualnya lagi dengan keuntungan setinggi mungkin sehingga nilai tukar dipandang lebih penting dibandingkan nilai pakai. Robert Albritton menjelaskan bahwa "...capitalism has its own inner logic. In other words, it has a life of its own that is not concerned with human flourishing, democracy or social justice, but instead is concerned with profits, which may or may not advance ethical norms as spin-offs." (Albritton, 2009:11). Oleh karena itu, jika merujuk pada pandangan Marx maka motif utama perusahaan melaksanakan program CSR semata-mata untuk memperoleh keuntungan ekonomi yang lebih besar di kemudian hari.

Untuk memperoleh keuntungan tersebut, maka dengan kekuasaan yang dimiliki program CSR mampu dikonstruksikan sedemikian rupa oleh perusahaan untuk mencapai tujuan utama yakni memperoleh sumberdaya produksi yang lebih besar. Foucault (Malik 2010) berpendapat bahwa pengetahuan dan kekuasaan saling bertautan, pengetahuan bukan merupakan pengungkapan samar-samar dari relasi kekuasaan tetapi pengetahuan berada di dalam relasi kekuasaan itu sendiri. Pandangan ini menunjukkan bahwa pengetahuan tentang realitas sosial tidak terlepas dari proses-proses kekuasaan yang terjadi didalamnya. Dalam kasus pengelolaan program CSR HIL, konstruksi pengetahuan pengelolaan program CSR HIL sangat dipengaruhi oleh konstelasi kepentingan dan kekuasaan yang terjadi di tiga ruang entitas sosial.

Dinamika pertarungan kepentingan dan kekuasaan dalam entitas sosial digambarkan melalui kontestasi kepentingan dan kekuasaan yang terjadi pada tatakelola program CSR HIL. Proses dialektika dalam tatakelola program CSR telah menyebabkan masyarakat kelas bawah 
menjadi termarginalkan, sehingga program CSR disusun bukan didasarkan pada kebutuhan masyarakat tetapi ditentukan oleh kepentingan kelas atas (masyarakat lapisan atas, pemerintah dan perusahaan). Proses marjinalisasi tersebut dapat dilihat dari proses perencanaan, pelaksanaan, monitoring dan evaluasi dalam tatakelola program. Pada proses perencanaan program CSR HIL, proses desentralisasi perencanaan program CSR kepada pemerintah desa yang semula dilakukan oleh perusahaan menjadi bias kepentingan elite desa.

Perencanaan program CSR HIL dilakukan melalui musrenbang dan FKM. Pada proses tersebut peserta yang hadir sekitar 90 persen adalah aparat desa dan tokoh masyarakat, sehingga penentuan program CSR HIL menjadi bias kelas atas. Disamping itu, pada kedua kelembagaan tersebut pengetahuan program CSR dikonstruksikan sebagai program bantuan sehingga masyarakat tidak dapat "menuntut" atau turut mengambil keputusan dalam mementukan jumlah dana program CSR.

Untuk mengusulkan program kepada perusahaan, proposal yang dibuat masyarakat harus mendapat persetujuan dari pemerintah desa. Pengetahuan ini dikonstruksi bersama baik oleh pemerintah desa maupun perusahaan. Pemerintah desa memiliki kepentingan untuk mengontrol atau "menguasai" program CSR untuk kepentingan kelas atas. Menurut Marx (Suseno 2003:116) kelas atas akan terus berusaha mempertahankan posisinya bukan karena secara pribadi rakus atau asosial tapi karena sistem sosiallah yang menyebabkan hal tersebut. Oleh karena itu, elite desa yang turut dalam menentukan program tersebut bukan untuk memperjuangkan kepentingan masyarakat lapisan atas, tetapi untuk kepentingan masyarakat lapisan atas. Disisi lain, dengan diberikannya wewenang kepada pemerintah desa maka perusahaan menjadi tidak direpotkan oleh urusan administrasi dan harus menghadapi besarnya tuntutan dari masyarakat. Artinya ketika konflik kepentingan terjadi dalam proses pengusulan program, maka konflik tersebut hanya berada di tingkat desa.

Pada proses pelaksanaan program CSR, kontestasi kepentingan dan kekuasaan juga terjadi pada proses penentuan sasaran dan lokasi program. Perencanaan program yang bias elite atau masyarakat lapisan atas menyebabkan penentuan sasaran dan lokasi program yang bias elite pula. Contoh kasus, dalam program pendidikan berupa beasiswa. Persyaratan yang diberikan oleh perusahaan beasiswa hanya untuk masyarakat yang kurang mampu, namun di lapang ditemukan bahwa beasiswa diberikan kepada masyarakat lapisan atas dengan alasan beasiswa tidak hanya diberikan kepada siswa dari keluarga kurang mampu juga kepada siswa berprestasi. Terlihat bahwa konstruksi kuasa pengetahuan yang dilakukan oleh pemerintah dan masyarakat lapisan atasturut menentukan sasaran penerima program CSR. Marx menjelaskan bahwa baik undang-undang atau aturan bukan yang membentuk masyarakat, tetapi masyarakatlah yang membentuk aturan atau undang-undang dan kelas ataslah yang diuntungkan oleh proses tersebut (Wheen 2006). Hal ini menunjukkan bahwa pengetahuan tentang tatakelola program CSR akan dikonstruksi sehingga program CSR memberikan keuntungan bagi pemerintah dan masyarakat lapisan atas.

\section{SIMPULAN DAN SARAN}

\section{Simpulan}

Program CSR sebagai perspektif strategi bisnis berasal dari ideologi kapitalisme. Marx menjelaskan bahwa sifat dasar kapitalisme adalah mencari keuntungan ekonomi sehingga program CSR HIL akan dikonstruksi untuk memberikan keuntungan ekonomi yang lebih besar. Terdapat 3 bentuk konstruksi kuasa pengetahuan pengelolaan program CSR yakni dalam relasi kekuasaan yaitu relasi antara masyarakat dengan pemerintah, pemerintah dengan perusahaan dan masyarakat dengan perusahaan. Dalam relasi-relasi tersebut program CSR HIL dikonstruksikan dalam dua bentuk yakni sebagai program bantuan dan program kewajiban perusahaan dengan pemangku kuasa pengetahuan terletak pada pemerintah dan perusahaan. Foucault (Malik 2010) berpendapat bahwa pengetahuan dan kekuasaan saling bertautan, pengetahuan bukan merupakan pengungkapan samar-samar dari relasi kekuasaan tetapi pengetahuan berada di dalam relasi kekuasaan itu sendiri. Pandangan ini menggambarkan bahwa program CSR adalah hasil dari konstestasi kepentingan dan kekuasaan yang terjadi pada relasi kekuasaan 
sebagai fenomena politik. Konstestasi ini pada akhirmya menghasilkan tatakelola program CSR HIL yang bias elite desa.

\section{Saran}

Saran yang bisa diberikan adalah perlunya untuk merubah proses-proses dalam musrenbang dan forum komunikasi masyarakat yang tidak bias elite desa dan bias gender, sehingga proses dialog dan penyadaran dapat terwujud. Selain itu, pemberdayaan politik dalam program CSR perlu dilakukan bagi seluruh stakeholder yang terlibat.

\section{DAFTAR PUSTAKA}

Ambadar J. 2008. CSR dalam Praktik di Indonesia: Wujud Kepedulian Dunia Usaha. PT Elex Media Komputindo. Jakarta.

Amri M, Sarosa W. 2008. CSR untuk Penguatan Kohesi Sosial. Indonesia Business Links. Jakarta.

Ardianto E, Machfudz DM. 2011. Efek Kedermawanan Pebisnis dan CSR Berlipat-Lipat. PT. Elex Media Komputindo. Jakarta.

Asrianti US. 2010. Analisis Pola Pelaksanaan Tanggung Jawab Sosial Perusahaan (CSR) Dalam Upaya Pengembangan Masyarakat: Studi Kasus Baitul Maal Wa Tamwil Swadaya PT Holcim Indonesia Tbk di Desa Kembang Kuning Kecamatan Klapanunggal, Kabupaten Bogor, Provinsi Jawa Barat. Skripsi. Departemen Sains Komunikasi dan Pengembangan Masyarakat IPB. Bogor.

Babbie E. 2004. The Practice of Social Research (10th Edition). Thomson Wadsworth. United States America.

Budimantra A. 2007. Kekuasaan dan Penguasaan Sumber Daya Alam. ICDS. Jakarta.

Bryman A. 2001. Social Research Methods (Second Edition). Oxford University Press. United States.

Crane, Andrew., Abagil Mc Williams, Dirk Matten, Jeremy Moon and Donald S. Siegel. 2008. The Oxford Handbook of
Corporate Social Responsibility. Oxford University Press.

Damsar. 2010. Pengantar Sosiologi Politik. Kencana Prenada Media Group. Jakarta.

Departemen Sains Komunikasi dan Pengembangan Masyarakat. Persepsi Komunitas dan Pemangku Kepentingan Lainnya terhadap Pengembangan Masyarakat dalam Kerangka Tanggung Jawab Sosial PT Holcim Indonesia Tbk Pabrik Narogong. Hasil Penelitian. Departemen Sains Komunikasi dan Pengembangan Masyarakat - FEMA IPB. Bogor.

Fajar M. 2010. Tanggung Jawab Sosial Perusahaan di Indonesia: Studi tentang Penerapan Ketentuan CSR pada Perusahaan Multinasional, Swasta Nasional dan BUMN di Indonesia. Pustaka Pelajar. Yogyakarta.

Friedmann J. 1991. Empowermnet: The politics of Alternative Development. Blackwell. Cambridge MA \& Oxford. UK

Foucault M. 1980. Power/Knowledge : Selected Interviews and Other Writing, terj. C. Gordon et al., Pantheon Random House, New York.

Foucault M. 2002. Pengetahuan dan Metode: Karya-karya Penting Foucault. Terjemahan dari $\mathrm{P}$ Rabinow, ed. Aesthetics, Method and Epistemology: Essential Works of Foucault 19541984. Jalasutra. Yogyakarta.

Giddens A. 2007. Kapitalisme dan Teori Sosial Modern: Suatu Analisis Karya Tulis Marx, Durkheim dan Max Webber. UI-Press. Jakarta.

Gilchrist A. 2004. The Well-Conected Community: A Networking Approach to Community Development. The Policy Press. University of Bristol, Bristol.

Guba, Egon G \& Yvonna S. Lincoln. 1994. Competing Paradigms in Qualitative Research, Dalam Denzin Eds. Handbook of Qualitative Research. 
Sage Publication Thousan Oaks. London.

Ife J. 1995. Community Development: Creating Community Alternatives, Vision, Analysis and Practice. Longman. Australia.

2002. Community Development: Community-based Alternatives in an Age of Globalisation. Pearson Education Australia. Australia.

Ife J, Tesoriero F. 2008. Community Development: Alternatif Pengembangan Masyarakat di Era Globalisasi. Pustaka Pelajar. Yogyakarta.

Jalal. 2011. Berdiri di Puncak Raksasa CSR. Majalah Bisnis \& CSR: Guide to Sustainability. Edisi 22 Tahun Keempat November 2011. Latofi Enterprise Media. Jakarta.

Johnson, Doyle Paul. 1986. Teori Sosiologi Klasik dan Modern Jilid 1. PT. Gramedia. Jakarta. 1986. Teori Sosiologi Klasik dan Modern Jilid 2. PT. Gramedia. Jakarta.

Kleden I. 2004. Masyarakat dan Negara: Sebuah Persoalan. Yayasan Indonesiatera. Magelang

Korten, David C. 2005. The Great Turning: From Empire to Earth Community. Kumarian Press. USA.

Korten, D.C. dan Syahrir (penyunting). 1988. Pembangunan Berdimensi Kerakyatan. Yayasan Obor Indonesia. Jakarta.

Lubis DP. 2007. Pemberdayaan Masyarakat: Konsep dan Strategi. Bahan Pelatihan Pengorganisasian Masyarakat untuk Tim Relawan P4T Teluk Bintuni Irian Jaya Barat. Bogor.

Malik A. 2010. Konstruksi Sosial Kuasa Pengetahuan Zakat (Studi Kasus Tiga Lembaga Zakat di Provinsi Jambi dan Sumatera Barat). Disertasi Program Studi Sosiolgi Pendesaan. Sekolah Pascasarjana IPB. Bogor.

Marzali A. 1999. Konsep Peisan dan Kajian Masyarakat Pedesaan di Indonesia. Jurnal Fisip UI. Jakarta.
Mills S. 2007. Diskursus: Sebuah Piranti Analisis dalam Kajian Ilmu Sosial. Penerbit Qalam. Jakarta.

Moratis L, Cochius T. 2011. ISO 26000: The Business Guide To The New Standard on Social Responsibility. Greenleaf Publishing Limited. UK.

Nasdian FT. 2006. "Kemitraan dalam Tata Pemerintahan Desa dan Pemberdayaan Komunitas Perdesaaan dalam Perspektif Kelembagaan" dalam Pembaharuan Tata Pemerintahan Desa Berbasis Lokalitas dan Kemitraan. PSP3-IPB dan Partnership of Governance Reform in Indonesia - UNDP. Bogor. 2007. Pemberdayaan Masyarakat Berbasis Ekologi dan Keadilan Sosial. Dalam buku: Ekologi Manusia (Editor: Soeryo Adiwibowo). Fakultas Ekologi Manusia IPB. Bogor. 2003. Pemberdayaan Tenaga Kerja Migran dan Kelembagaan Koperasi dalam Pembangunan Pedesaan. Makalah hasil penelitian Riset Unggulan Terpadu. Bogor.

Nursahid F. 2006. Praktik Kedermawanan Sosial BUMN: Analisis terhadap Model Kedermawanan PT. Krakatau Steel, PT. Pertamina dan PT. Telkom. Dalam Galang: Jurnal Filantropi dan Masyarakat Madani. Vol 1, No 2, Januari 2006. PIRAC. Jakarta.

Parson, Ruth J., Jams D. Jorgensen dan Santos H. Hernandez. 1994. The Integration of Social Work Practice. Brooks/Cole. California.

Poloma, Margaret M. 1994. Sosiologi Kontemporer. Rajawali Press. Jakarta.

Pranarka AMW, Moeljarto V. 1996. Pemberdayaan (Empowerment) dalam Pemberdayaan: Konsep, Kebijakan dan Implementasi. Disunting oleh Onny S. Projono dan AMW Pranarka. CSIS. Jakarta.

Prayogo D. 2008. Konflik Antara Korporasi dengan Komunitas Lokal: Sebuah Kasus Empirik pada Industri 
Geotermal di Jawa Barat. Fisip UI Press. Jakarta.

2011. Socially Responsible Corporation: Peta Masalah, Tanggung Jawab Sosial dan Pembangunan Komunitas pada Industri Tambang dan Migas di Indonesia. UI-Press. Jakarta.

Rachman, Nurdizal M., Asep Efendi dan Emir Wicaksono. 2011. Panduan Lengkap Perencanaan Corporate Social Responsibility. Penebar Swadaya. Jakarta.

Radyati MRN. 2008. CSR untuk Pemberdayaan Ekonomi Lokal. Indonesia Business Links. Jakarta.

Rahman R. 2009. Corporate Social Responsibility: Antara Teori dan Kenyataan. MedPress. Yogyakarta.

Ritzer G, Smart B. 2011. Handbook Teori Sosial. Nusa Media. Bandung.

Ritzer G. 2012. Teori Sosiologi: Dari Sosiologi Klasik Sampai Perkembangan Terakhir Postmodern. Pustaka Pelajar. Yogyakarta.

Salam M. 2011. Dialog Paradigma Metodologi Penelitian Sosial. Masagena Press. Makasar.

Soetomo. 2011. Pemberdayaan Masyarakat: Mungkinkah Muncul Antitesisnya? Pustaka Pelajar. Yogyakarta.

Sukada S, Pamadi Wibowo, Katamsi Ginano, Jalal, Irpan Kadir dan Taufik Rahman. 2007. Membumikan Bisnis Berkelanjutan: Memahami Konsep \& Praktik Tanggungjawab Sosial Perusahaan. Indonesia Business Links. Jakarta.

Sumaryo. 2009. Implementasi Tanggungjawab Sosial Perusahaan (Corporate Social Responsibility) dalam Pemberdayaan dan Peningkatan Kesejahteraan Masyarakat: Kasus di Provinsi Lampung. Disertasi. Sekolah Pascasarjana Institut Pertanian Bogor. Bogor.

Suseno FM. 2003. Pemikiran Karl Marx: Dari Sosialisme Utopis ke Perselisihan Revisionisme. PT. Gramedia Pustaka Utama. Jakarta.
Wheen F. 2006. Das Kapital: Kisah Sebuah Buku yang Mengubah Dunia. PT. Wahana Aksi Kritika. Jakarta.

Wulan TR. 2010. Pengetahuan dan Kekuasaan: Penguatan Remiten Sosial sebagai Strategi Pemberdayaan Buruh Migran Perempuan. Disertasi Program Studi Sosiolgi Pendesaan. Sekolah Pascasarjana. IPB. Bogor.

Zainal RI. 2006. Best Practices: Corporate Social Responsibility (CSR) Sebuah Pengalaman Membangun Multistakeholder Engagement bagi Penerapan CSR di Kabupaten Muba, Sumatera Barat. Usaha Musi. Palembang. 
Siwi / JSKPM 1(1): 115-128 